\title{
Comparative proteomics of side population cells derived from human hepatocellular carcinoma cell lines with varying metastatic potentials
}

\author{
HONGZHI LIU ${ }^{1}$, YINGCHAO WANG ${ }^{2,3}$, XIAOHUA XING ${ }^{2,3}$, YING SUN $^{2,4}$, DAHAI WEI $^{2,3}$, GENG CHEN $^{2,3}$, \\ QINYING LIU ${ }^{5}$, SHANSHAN CHEN ${ }^{5}$, XIAOLONG LIU ${ }^{2,3}$ and JINGFENG LIU ${ }^{1-3,6}$ \\ ${ }^{1}$ Liver Disease Center, The First Clinical Medical College of Fujian Medical University, Fuzhou, Fujian 350005; \\ ${ }^{2}$ The United Innovation of Mengchao Hepatobiliary Technology Key Laboratory of Fujian Province, \\ Mengchao Hepatobiliary Hospital of Fujian Medical University; ${ }^{3}$ The Liver Center of Fujian Province, \\ Fujian Medical University, Fuzhou, Fujian 350025; ${ }^{4}$ College of Life Sciences, Fujian Agriculture and \\ Forestry University, Fuzhou, Fujian 350002; ${ }^{5}$ Fujian Provincial Key Laboratory of Tumor Biotherapy, \\ Teaching Hospital of Fujian Medical University, Fujian Provincial Tumor Hospital, Fuzhou, Fujian 350014; \\ ${ }^{6}$ Liver Disease Center, The First Affiliated Hospital of Fujian Medical University, Fuzhou, Fujian 350007, P.R. China
}

Received August 16, 2016; Accepted March 16, 2018

DOI: $10.3892 / \mathrm{ol} .2018 .8666$

\begin{abstract}
Metastasis and recurrence following surgery are major reasons for the high mortality rate and poor prognosis associated with hepatocellular carcinoma (HCC). Cancer stem cells (CSCs) are thought to be able to cause cancer, and to be the primary cause of tumor recurrence and metastasis. The underlying mechanisms of the metastatic potential of CSCs is poorly understood. In the present study, side population (SP) cells were isolated from 4 HCC cell lines, and their self-renewal and migratory abilities were compared. The results demonstrate that SP cells from different cell lines
\end{abstract}

Correspondence to: Dr Xiaolong Liu or Dr Jingfeng Liu, The United Innovation of Mengchao Hepatobiliary Technology Key Laboratory of Fujian Province, Mengchao Hepatobiliary Hospital of Fujian Medical University, 312 Xihong Road, Fuzhou, Fujian 350025, P.R. China

E-mail: xiaoloong.liu@gmail.com

E-mail: drjingfeng@126.com

Abbreviations: HCC, hepatocellular carcinoma; CSCs, cancer stem cells; SP, side population; MP, main population; ABC, ATP-binding cassette; MS, mass spectrometry; iTRAQ, isobaric tags for relative and absolute quantitation; 2D LC-MS/MS, two-dimensional liquid chromatography-tandem mass spectrometry; TEAB, triethylammonium bicarbonate; DTT, D-dithiothreitol; IAA, iodoacetamide; FDR, false discovery rate; GO, Gene Ontology; IPA, ingenuity pathway analysis; DEPs, differentially expressed proteins; EMT, epithelial-mesenchymal transition

Key words: hepatocellular carcinoma, metastasis, quantitative proteomics, isobaric tags for relative and absolute quantification, side population cells, cancer stem cells exhibited similar self-renewal abilities but different metastatic potentials. Furthermore, the overall proteomes of the SP cells were systematically quantified. This revealed 11 and 19 differentially expressed proteins (DEPs), upregulated and downregulated, respectively, associated with increased metastatic potential. These proteins were involved in the 'regulation of mRNA processing' and 'cytoskeleton organization' biological processes. The majority of the proteins were involved in 'cell proliferation', 'migration' and 'invasion of cancer', and may promote HCC metastasis in a synergistic manner. The $\mathrm{AKT}$ and nuclear factor- $\mathrm{\kappa B}$ signaling pathways may contribute to the regulation of HCC metastasis through regulating the DEPs in SP cells. To the best of our knowledge, the present study is the first to demonstrate the overall proteome difference among SP cells from the different HCC cell lines with different metastatic potentials. The present study provides novel information regarding the metastatic potential of CSCs, which will facilitate further investigation of the topic.

\section{Introduction}

Hepatocellular carcinoma (HCC) is among the most common types of malignant tumor, and ranked fifth globally in terms of incidence. It is also the third most common cause of cancer-associated mortality worldwide (1). HCC has an incidence of $\sim 466,100 /$ year in China, according to a 2015 study by The National Central Cancer Registry of China (2). Surgical resection is the first-line treatment for patients with early-stage HCC, which can be curative $(3,4)$. However, the rate of metastasis and recurrence following surgery remains high, which is a major obstacle for improving the clinical outcome of patients with HCC (5). Evidence suggests that tumor recurrence and metastasis are associated with cancer stem cells (CSCs) in various types of cancer, including HCC (6). CSCs are reported to have inherent tumor initiating 
potential, serving important roles in tumor relapse, driving primary tumor growth, and the seeding and establishment of metastases (7). Recently, CSCs have been investigated as a therapeutic target.

Clinical observations and experimental data have indicated heterogeneity among cancer cell lines in terms of aggressive potential, suggesting that CSCs from different sourced may have varying migration ability (8-10). A previous study demonstrated that the percentage of CSCs was positively correlated with the metastatic potential of the parent cell line (11). However, it remains to be determined whether CSCs derived from different cell lines/tumors possess different metastatic capabilities. Side population (SP) cells, are a subset of cells with the ability to efflux Hoechst 33342 in flow cytometry through an ATP-binding cassette (ABC) membrane transporter, and were first described by Goodell et al (12) in the bone marrow. SP cells isolated from various cancer cell lines have been demonstrated to exhibit stem cell-like properties (13-16). In the present study, SP cells were employed as a model to study the molecular differences in the metastatic potential of CSCs derived from different cell lines.

High-throughput quantitative proteomic technologies provide a powerful tool for systematically characterizing the overall proteome alterations underlying physiological or pathological changes. Isobaric tags for relative and absolute quantification (iTRAQ) is an ultrasensitive and precise approach for studying protein quantitative changes in $\leq 8$ samples simultaneously $(17,18)$. Comparative proteomic approaches coupled with iTRAQ are widely used to investigate the molecular mechanisms of tumorigenesis, metastasis and recurrence of HCC (19-21). iTRAQ-based quantitative study of protein expression profiles between CSCs and their parental cell lines have also been reported (22). However, to the best of our knowledge, the application of iTRAQ labeling in studying the molecular differences among CSCs from cell lines with different metastatic potentials has not been previously reported. In the present study, an iTRAQ based quantitative proteomic approach was used to systematically compare the overall proteome profiles among different SP cells to reveal the underlying molecular mechanisms of HCC cell lines with different metastatic potentials.

\section{Materials and methods}

Cell culture. The human HCC HCCLM3, MHCC97-H and MHCC97-L cell lines were purchased from The Cell Bank of Type Culture Collection of Chinese Academy of Science, Shanghai Institute for Biological Sciences (Shanghai, China). The HCC cell line, Hep3B, was purchased from the America Type Culture Collection (Manassas, VA, USA). HCCLM3, MHCC97-H, MHCC97-L cells were cultured in high-glucose DMEM containing 10\% FBS, $100 \mathrm{U} / \mathrm{ml}$ penicillin and $100 \mu \mathrm{g} / \mathrm{ml}$ streptomycin (all reagents from Gibco; Thermo Fisher Scientific, Inc., Waltham, MA, USA). Hep3B was cultured in MEM (Gibco; Thermo Fisher Scientific, Inc.) with $10 \%$ FBS. All cells were incubated at $37^{\circ} \mathrm{C}$ in a humidified atmosphere containing $5 \% \mathrm{CO}_{2}$.

Flow cytometry (FCM) analysis of SP cells. The 4 cell lines were cultured to $80 \%$ confluence and detached using $0.25 \%$
Trypsin-EDTA, then suspended in DMEM supplemented with $3 \% \mathrm{FBS}$, at a density of $1 \times 10^{6}$ cells $/ \mathrm{ml}$. The cells were then incubated with $20 \mu \mathrm{g} / \mathrm{ml}$ Hoechst 33342 (Sigma-Aldrich; Merck KGaA, Darmstadt, Germany) alone or with $25 \mu \mathrm{g} / \mathrm{ml}$ verapamil (Sigma-Aldrich; Merck KGaA) at $37^{\circ} \mathrm{C}$ for $90 \mathrm{~min}$. Verapamil was used as a guiding parameter to determine the boundary between SP and main population (MP) cells. The samples were centrifuged at $300 \mathrm{xg}$ for $5 \mathrm{~min}$ at $4^{\circ} \mathrm{C}$, and then re-suspended in PBS supplemented with 3\% FBS. Propidium iodide (PI; Sigma-Aldrich; Merck KGaA) was added at $1 \mu \mathrm{g} / \mathrm{ml}$ to exclude analysis of any dead cells. FCM analysis was performed using a Moflo XDP flow cytometer (Beckman Coulter, Inc., Brea, CA, USA), as previously described (23). Each assay was performed in triplicate.

Sphere formation assay and soft agar colony formation assay. For the sphere formation, SP and MP cells sorted from the 4 cell lines were suspended separately in serum-free DMEM/F12 medium (Gibco; Thermo Fisher Scientific, Inc.) supplemented with $20 \mathrm{ng} / \mathrm{ml}$ epidermal growth factor, $10 \mathrm{ng} / \mathrm{ml}$ basic fibroblast growth factor and $10 \mu \mathrm{l} / \mathrm{ml} \mathrm{B} 27$ (all from Gibco; Thermo Fisher Scientific, Inc.). The cells were then plated into 6-well UltraLow Attachment plates (Corning Incorporated, Corning, NY, USA) at $2 \times 10^{3}$ cells/well. After 14 days, the number of spheres were counted under a confocal microscope (magnification, x50). For the soft agar colony formation assay, sorted SP and MP cells were seeded into 6-well plates at $5 \times 10^{3}$ cells/well in $0.3 \%$ agarose (Promega Corporation, Madison, WI, USA) over a $0.6 \%$ agarose layer. After 14 days, the number of colonies were counted under confocal microscope (magnification, x50).

Cell migration assay. The migration assays were performed using Transwell plates (pore diameter, 8- $\mu \mathrm{m}$; Corning Incorporated), according to the manufacturer's instructions. A total of $100 \mu \mathrm{l} \mathrm{SP}$ and MP cells at $1 \times 10^{6}$ cells $/ \mathrm{ml}$ were cultured in the upper chamber in serum-free DMEM supplemented with $0.5 \%$ BSA. A total of $600 \mu 1$ DMEM supplemented with $10 \%$ FBS was added to the lower chamber. After $48 \mathrm{~h}$, non-migrating cells on the upper surface of the filters were removed with cotton swabs, and cells on the lower membrane of the filters were fixed with $4 \%$ paraformaldehyde, and stained with $0.1 \%$ hematoxylin (Beyotime Institute of Biotechnology, Haimen, China) for $20 \mathrm{~min}$ at room temperature. The stained cells, which had passed through the filter to the lower surface, were counted under a confocal microscope in 5 randomly selected fields of view (magnification, x200).

Protein preparation and iTRAQ labeling. A total of $500 \mu 1$ lysis buffer [8 M urea (Sigma-Aldrich, Merck KgaA), 50 mM $\mathrm{NH}_{4} \mathrm{HCO}_{3}, 50 \mathrm{mM}$ iodoacetamide (IAA) and $1 \mathrm{X}$ protease inhibitor cocktail (Roche Diagnostics, Basel, Switzerland)] was added to the 4 types of SP and MP cells, followed by sonication for $8 \mathrm{~min}$ with a period of $1 \mathrm{sec}$ sonication and $5 \mathrm{sec}$ pause at $190 \mathrm{~W}$ on ice. Following centrifugation at $17,000 \mathrm{x} \mathrm{g}$ for $10 \mathrm{~min}$ at $4^{\circ} \mathrm{C}$, the supernatant was collected. The protein concentration of the supernatant was determined by BCA assay (TransGen Biotech, Co., Ltd., Beijing, China), according manufacturer's protocol. Then, $100 \mu \mathrm{g}$ protein was adjusted to a final volume of $100 \mu \mathrm{l}$ in $100 \mathrm{mM}$ triethylammonium bicarbonate (TEAB). A total of $8 \mu 1$ DTT (1M) was 
added to the protein samples and incubated at $55^{\circ} \mathrm{C}$ for $1 \mathrm{~h}$, followed by the addition of $10 \mu 1500$ mM IAA, and another incubation for $30 \mathrm{~min}$ in the dark at room temperature to alkylate the proteins. The proteins were re-dissolved in $100 \mu \mathrm{l}$ TEAB (100 mM), and then digested by sequence-grade modified trypsin (Promega Corporation) at $37^{\circ} \mathrm{C}$ for $16 \mathrm{~h}$, and the resultant peptide mixture was labeled using chemicals from the iTRAQ reagent kit (cat. no. 4381663, Sigma-Aldrich Merck $\mathrm{KGaA}$ ), according to the manufacturer's protocol. The peptides from Hep3B, MHCC97-L, MHCC97-H and HCCLM3 MP cells were labeled with 113, 115, 117 and 119 isobaric tags, respectively; and the peptides from the SP cells of the 4 HCC cell lines were labeled with 114, 116, 118 and 121 isobaric tags, respectively. Equal amounts of labeled samples were mixed together, and desalted in Sep-Pak Vac C18 cartridges (Waters Technologies Corporation, Milford, MA, USA) and dried in a vacuum centrifuge.

High $\mathrm{pH}$ reverse phase separation and low $\mathrm{pH}$ two dimensional-liquid chromatography-tandem mass spectrometry (2D-LC-MS/MS) analysis. The peptide mixture was re-dissolved in solution $\mathrm{A}(10 \%$ acetonitrile $(\mathrm{ACN})$ in water, $\mathrm{pH}$ 10.0), and fractionated by high $\mathrm{pH}$ separation using a 1260 Infinity LC system (Agilent Technologies, Inc., Santa Clara, CA, USA) connected to a reverse phase column (Durashell C18, $5 \mu \mathrm{m}, 4.6 \times 250 \mathrm{~mm}$; Phenomenex ${ }^{\circledR}$, Torrance, CA, USA). High $\mathrm{pH}$ separation was performed with a linear gradient of $0-80 \%$ solution $\mathrm{B}(95 \% \mathrm{ACN}$ in water, $\mathrm{pH} 10.0)$ for $80 \mathrm{~min}$ at a flow rate of $700 \mu \mathrm{l} / \mathrm{min}$. Following separation, the column was re-equilibrated with solution A for $15 \mathrm{~min}$. A total of 10 fractions were collected and dried in a vacuum concentrator. The fractions were analyzed using an EASY-nLC1000 system (Thermo Fisher Scientific, Inc.) connected to a Q Exactive Quadrupole-Orbitrap mass spectrometer (Thermo Fisher Scientific, Inc.) equipped with an online nano-electrospray ion source. Each fraction was re-suspended in $80 \mu 1$ solution C ( $0.1 \%$ formic acid in water). The samples were then separated by nano-LC and analyzed using the online electrospray tandem mass spectrometry as follows. A total of $10 \mu 1$ peptide sample was loaded onto a trap column (Acclaim PepMap C18, $100 \mu \mathrm{m}$ x $2 \mathrm{~cm}$; Thermo Scientific, Inc.). Subsequently, it was separated in an analytical column (Acclaim PepMap C18, $75 \mu \mathrm{m} \times 15 \mathrm{~cm})$ with a linear gradient of $2-80 \%$ solution D $(0.1$ $\%$ formic acid in $\mathrm{ACN}$ ) over $2 \mathrm{~h}$ with a flow rate of $300 \mathrm{nl} / \mathrm{min}$ at $40^{\circ} \mathrm{C}$. Finally, the column was re-equilibrated with solution $\mathrm{C}$ for $15 \mathrm{~min}$. The solutions $\mathrm{A}, \mathrm{B}, \mathrm{C}$ and $\mathrm{D}$ were all produced in-house. The Q-Exactive mass spectrometer was operated in the data dependent mode to switch mechanically between MS and MS/MS acquisitions. MS spectra (m/z 300-1,500) were acquired with a mass resolution of $70,000 \mathrm{HZ}$, followed by 20 sequential high energy collisional dissociation MS/MS scans with a resolution of 17,500 $\mathrm{HZ}$. One microscan was recorded using a dynamic exclusion of $20 \mathrm{sec}$ for all cases.

Database searching and criteria. Protein identification was performed using Proteome Discoverer (version 1.4; Thermo Fisher Scientific, Inc.) against a database provided by The Universal Protein Resource (www.uniprot.org/uniprot; released, 2014-04-10). The enzyme specificity of trypsin was used and $\leq 2$ missed cleavages were allowed for protease digestion. Proteome Discoverer was searched with a parent ion tolerance of 10 parts per million and a fragment ion mass tolerance of $0.02 \mathrm{Da}$. Carboxymethyl of cysteine was specified as a fixed modification. iTRAQ modification of peptide $\mathrm{N}$-terminus, oxidation of methionine, deamination of asparagine and glutamine, and iTRAQ 8-plex labeling of lysine and tyrosine residues were set as variable modifications. Scaffold software (version 4.4.5; Proteome Software Inc., Portland, OR, USA) was used to estimate the false discovery rate (FDR) and validate the MS/MS-based peptide and protein identifications. The proteins were assembled using the parsimony method and accepted with a peptide FDR $<1 \%$ and a protein probability $>90 \%$. Proteins containing similar peptides, which could not be distinguished based on MS/MS analysis alone, were grouped to satisfy the principles of parsimony. All results were then exported into Excel 2010 (Microsoft Corporation, Redmond, WA, USA) for data interpretation. To identify the differentially expressed proteins (DEPs), the relative protein expression values were compared among the 4 SP cell groups. The proteins were considered to be differentially expressed if the iTRAQ ratios were $>1.5$ or $<0.67$ when LM3-SP/MP cells were compared with Hep3B-SP/MP cells. The DEPs of SP and MP were analyzed using a Venn diagram (http://bioinformatics.psb.ugent.be/webtools/Venn/), and trends in the expression values of the DEPs of SP cells specially were analyzed using Excel 2010 (Microsoft Corporation, Redmond, WA, USA). The protein expression levels that were upregulated or downregulated with increasing metastatic potential in the 4 HCC SP cell groups are summarized in Table I.

Functional analysis of the differentially expressed proteins. The Gene Ontology (GO) annotation and pathway enrichment analysis of the differentially expressed proteins and clustered proteins was performed using the Database for Annotation, Visualization and Integrated Discovery (https://david.ncifcrf. gov/). GO annotation included biological processes, cellular components and molecular functions. The biological function and signaling pathway annotations of the differentially expressed proteins were analyzed by Ingenuity Pathway Analysis (IPA) software (version 7.5, Qiagen GmbH, Hilden Germany). The GO annotations were ranked in terms of the level of enrichment of the differentially expressed proteins.

Statistical analysis. All data are expressed as the mean \pm standard deviation. Statistical analysis was performed using one-way analysis of variance followed by Tukey's test. $\mathrm{P}<0.05$ was considered to indicate a statistically significant difference. Statistical analysis was performed using SPSS software (version 17; SPSS, Inc., Chicago, IL, USA).

\section{Results}

Identification and characterization of SP cells. 97-L, 97-H and LM3 cell lines possess identical genetic backgrounds and progressively increased metastatic potential (24). The Hep3B cell line has low metastatic potential. These cell lines have been used widely in the study of the HCC metastasis $(24,25)$. In the present study, the $4 \mathrm{HCC}$ cell lines were analyzed by dual wavelength fluorescence-activated cell sorting following incubation with Hoechst 33342. Representative results are 
Table I. Differentially expressed proteins among SP cells with increasing metastatic potentials.

\begin{tabular}{|c|c|c|c|c|}
\hline Accession number & Protein name & $\begin{array}{c}\text { iTRAQ ratio } \\
\text { (97-L SP/Hep3B SP) }\end{array}$ & $\begin{array}{c}\text { iTRAQ ratio } \\
\text { (97-H SP/Hep3B SP) }\end{array}$ & $\begin{array}{c}\text { iTRAQ ratio } \\
\text { (LM3 SP/Hep3B SP) }\end{array}$ \\
\hline NPM_HUMAN & Nucleophosmin & 0.76 & 0.74 & 0.66 \\
\hline NCBP1_HUMAN & Nuclear cap-binding protein subunit 1 & 0.83 & 0.77 & 0.63 \\
\hline TIGAR_HUMAN & Fructose-2,6-bisphosphatase TIGAR & 0.83 & 0.82 & 0.66 \\
\hline PRDX4_HUMAN & Peroxiredoxin-4 & 0.53 & 0.53 & 0.53 \\
\hline ADIRF_HUMAN & Adipogenesis regulatory factor & 0.65 & 0.56 & 0.56 \\
\hline CIP2A_HUMAN & Protein CIP2A & 0.84 & 0.79 & 0.63 \\
\hline ECI1_HUMAN & $\begin{array}{l}\text { Enoyl-CoA disomerase 1, } \\
\text { mitochondrial }\end{array}$ & 0.75 & 0.72 & 0.66 \\
\hline ITB1_HUMAN & Integrin $\beta-1$ & 0.80 & 0.79 & 0.62 \\
\hline PCM1_HUMAN & Pericentriolar material 1 protein & 0.81 & 0.65 & 0.51 \\
\hline HS74L_HUMAN & Heat shock $70 \mathrm{kDa}$ protein $4 \mathrm{~L}$ & 0.87 & 0.77 & 0.67 \\
\hline KV203_HUMAN & Igkchain V-II region MIL & 0.62 & 0.55 & 0.50 \\
\hline DIC_HUMAN & Mitochondrial dicarboxylate carrier & 0.98 & 0.83 & 0.62 \\
\hline PAK2_HUMAN & $\begin{array}{l}\text { Cluster of Serine/threonine-protein } \\
\text { kinase PAK } 2\end{array}$ & 0.72 & 0.70 & 0.58 \\
\hline RBM39_HUMAN & RNA-binding protein 39 & 0.84 & 0.79 & 0.55 \\
\hline DDX17_HUMAN & $\begin{array}{l}\text { Probable ATP-dependent RNA } \\
\text { helicase DDX17 }\end{array}$ & 0.68 & 0.65 & 0.64 \\
\hline XRCC5_HUMAN & $\begin{array}{l}\text { X-ray repair cross-complementing } \\
\text { protein } 5\end{array}$ & 0.73 & 0.72 & 0.66 \\
\hline TXTP_HUMAN & $\begin{array}{l}\text { Tricarboxylate transport protein, } \\
\text { mitochondrial }\end{array}$ & 0.58 & 0.55 & 0.52 \\
\hline SPCS2_HUMAN & Signal peptidase complex subunit 2 & 0.71 & 0.66 & 0.56 \\
\hline RM38_HUMAN & $\begin{array}{l}\text { 39S ribosomal protein } \mathrm{L} 38 \text {, } \\
\text { mitochondrial }\end{array}$ & 0.65 & 0.59 & 0.52 \\
\hline PPID_HUMAN & Peptidyl-prolyl cis-trans isomerase D & 1.01 & 1.10 & 1.53 \\
\hline SNX3_HUMAN & Sorting nexin-3 & 1.16 & 1.26 & 1.53 \\
\hline MRP1_HUMAN & $\begin{array}{l}\text { Multidrug resistance-associated } \\
\text { protein } 1\end{array}$ & 1.26 & 1.80 & 2.14 \\
\hline GET4_HUMAN & $\begin{array}{l}\text { Golgi to ER traffic protein } \\
4 \text { homolog }\end{array}$ & 3.97 & 4.07 & 4.62 \\
\hline GNL3_HUMAN & $\begin{array}{l}\text { Guanine nucleotide-binding } \\
\text { protein-like } 3\end{array}$ & 1.09 & 1.43 & 1.63 \\
\hline DNJB1_HUMAN & $\begin{array}{l}\text { DnaJ homolog subfamily B } \\
\text { member } 1\end{array}$ & 1.34 & 1.35 & 1.63 \\
\hline CHRD1_HUMAN & $\begin{array}{l}\text { Cysteine and histidine-rich } \\
\text { domain-containing protein } 1\end{array}$ & 1.07 & 1.22 & 1.52 \\
\hline ALDR_HUMAN & Aldose reductase & 1.44 & 1.51 & 1.55 \\
\hline PSD12_HUMAN & $\begin{array}{l}26 \mathrm{~S} \text { proteasome non-ATPase } \\
\text { regulatory subunit } 12\end{array}$ & 1.39 & 1.41 & 1.55 \\
\hline TKT_HUMAN & Transketolase & 1.40 & 1.42 & 1.59 \\
\hline CERU_HUMAN & Ceruloplasmin & 1.08 & 1.33 & 1.67 \\
\hline
\end{tabular}

iTRAQ, isobaric tags for relative and absolute quantification; SP, side population.

presented in Fig. 1A, the proportion of SP cells in Hep3B, 97-L, 97-H, and LM3 were 0.79, 2.27, 4.21 and 6.03\%, respectively. The proportion of SP cells increased with the metastatic potentials of their parent cell lines, which is consistent with previous reports.
To assess the CSC characteristics of the sorted SP and MP cells, they were subjected to a sphere formation assay. On day 3 , sorted SP cells began to form spheres, whereas MP cells formed no floating spheres and eventually died. Upon spheres dispersal into single cells, secondary and tertiary spheres also 

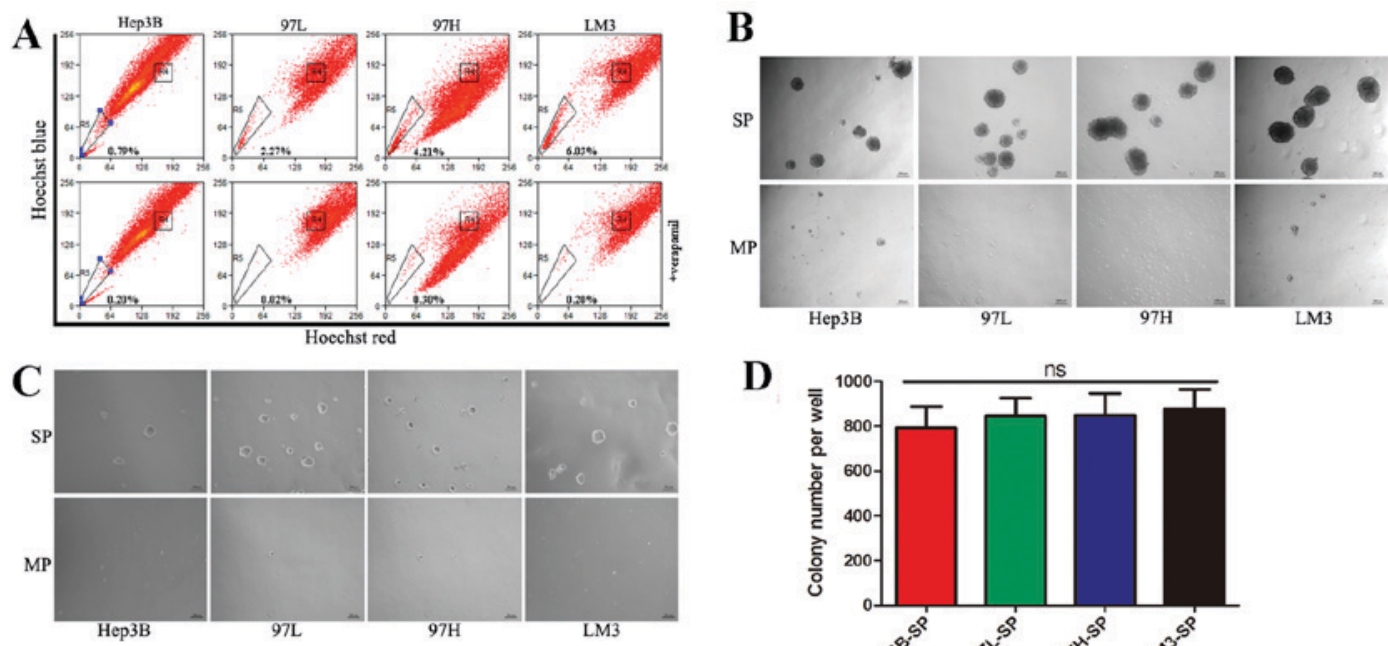

D
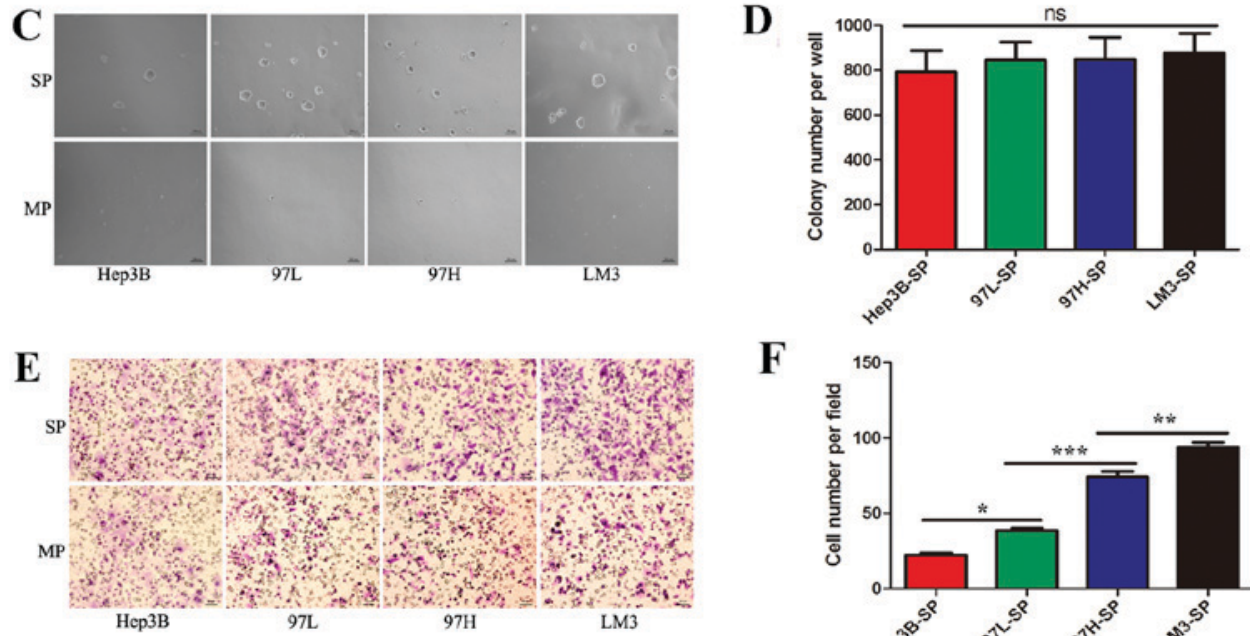

$\mathbf{F}$

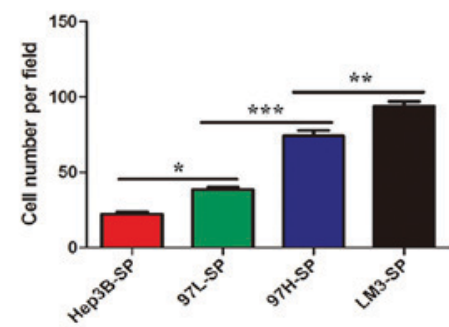

Figure 1. Identification of side population cells and the characteristics of each subpopulation. (A) Identification of SP cells by flow cytometry in the HCC cell lines, Hep3B, MHCC97L, MHCC97H and HCCLM3. (B) SP and MP cells were cultured in serum-free medium for 2 weeks (x50, magnification) to analyze sphere formation. (C) Representative images of the soft agar colony formation assays, in which SP and MP cells were seeded into a 6 -well plate at $5 \times 10^{3}$ cells/well in $0.3 \%$ agarose over a $0.6 \%$ agarose bottom layer for 2 weeks (x 50, magnification). (D) Quantification of the colony formation assay demonstrated there was no significant difference in self-renewal ability among SP cells derived from the different cell lines. (E) Representative images of migration assay. (F) Quantification of the migration assay revealed that the metastatic abilities of SP cells from the different cell lines increased progressively from Hep3B-SP to 97L-SP, to 97H-SP, to LM3-SP. SP, side population; HCC, hepatocellular carcinoma; MP, main population; 97L, MHCC97-L; 97H, MHCC97-H; LM3, HCCLM3. ${ }^{*} \mathrm{P}<0.05,{ }^{* *} \mathrm{P}<0.01$ and ${ }^{* * *} \mathrm{P}<0.001$

formed. SP cells of the 4 cell lines demonstrated a similar ability to form spheres (Fig. 1B).

In order to compare self-renewing capacity, the sorted SP and MP cells were subjected to soft agar colony formation assays. After 2 weeks, there was no significant difference in terms of colony number among SP cells derived from the different cell lines (Fig. 1C and D).

To assess metastatic ability, the sorted SP and MP cells were subjected to a Transwell migration assay. SP cells exhibited a high metastatic ability compared with MP cells. Furthermore, the metastatic ability increased progressively from Hep3B-SP to $97 \mathrm{~L}-\mathrm{SP}$, to $97 \mathrm{H}-\mathrm{SP}$, to LM3-SP cells (Fig. 1E and F).

Proteomic analysis of the SP cells and relative quantification of proteome of the side population cells. A quantitative MS-based discovery strategy was applied to study the overall proteome of SP cells. Total proteins extracted from the cells were analyzed using iTRAQ and 2D-LC-MS/MS, and the workflow is illustrated in Fig. 2. Scaffold software was used to identify a total of 1,670 proteins (Fig. 3A), then GO annotation was applied. As summarized in Fig. 3B, the top 3 molecular functions associated with the identified proteins were 'translation', 'RNA processing' and 'protein localization'.

Expression trends of proteins and GO analysis. To systematically analyze the molecular differences between SP cell groups, the relative protein expression values were compared. A mean fold change of $>1.5$ or $<0.67$ in relative protein expression between LM3 and Hep3B cells was indicative of differential expression. A total of 198 differentially expressed proteins (DEPs; 57 upregulated and 141 downregulated) were identified when LM3-SP cells were compared with Hep3B-SP cells; 98 DEPs (48 upregulated and 50 downregulated) were identified when LM3-MP cells were compared with Hep3B-MP cells. The DEPs of SP (198 DEPs) and MP (98 DEPs) were analyzed using a Venn diagram. There were 47 joint DEPs appeared in both SP and MP cells. Furthermore, there were 51 DEPs observed in MP cells and 151 DEPs were observed in the SP cells (Fig. 3C), suggesting that there may be different molecular mechanisms between SP and MP cells in $\mathrm{HCC}$.

Furthermore, the relative protein levels of 151 DEPs observed in the SP cells were analyzed using Excel 2010. There were 8 trends identified according to the the relative protein level of Hep3B-SP, 97L-SP, 97H-SP and LM3-SP. A number of DEPs increased progressively in expression from Hep3B-SP to LM3-SP (Fig. 4A) and a number of DEPs decreased progressively from Hep3B-SP to LM3-SP (Fig. 4H). The expression of other DEPs altered non-linearly between groups (Fig. 4B-G). A total of 11 and 19 differentially expressed proteins (DEPs) were upregulated and downregulated, respectively, with increasing metastatic potentials (Table I). These 30 DEPs formed clearly 


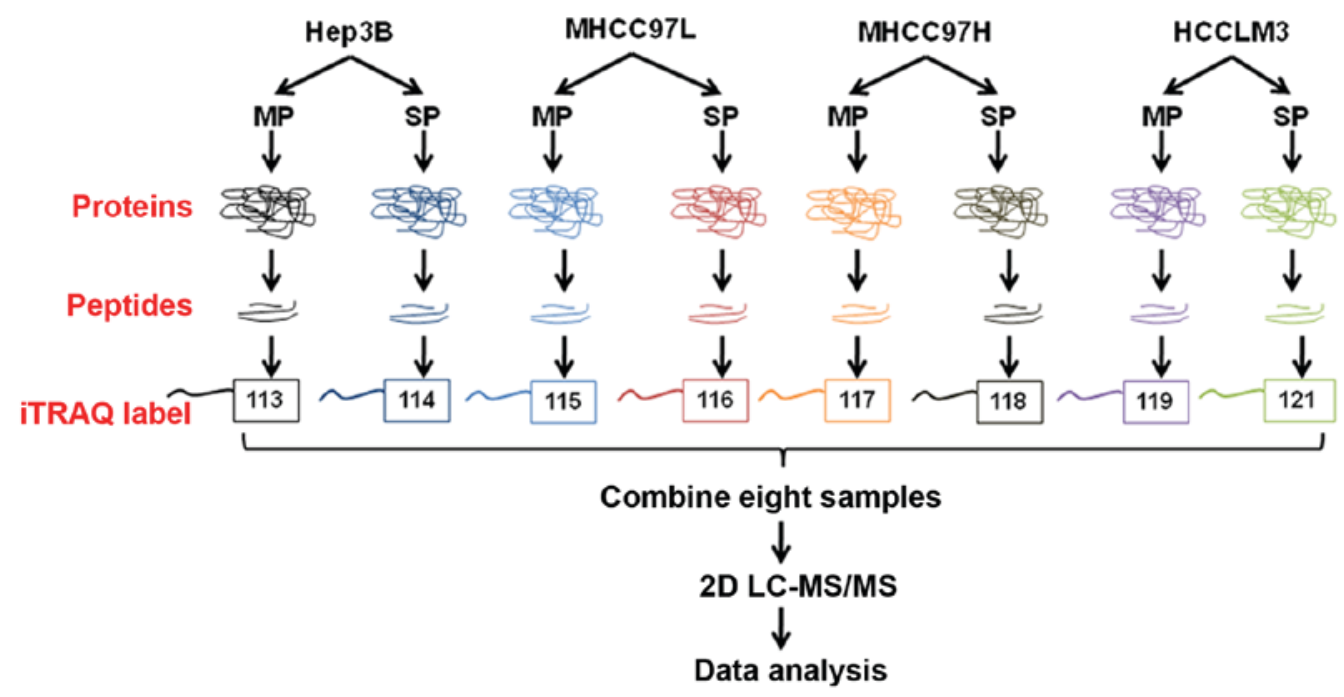

Figure 2. The workflow of the proteomic study. SP and MP cells were subjected to tryptic digestion, labeled with iTRAQ reagents, and combined for fractionation, followed by LC-MS/MS and data analysis. SP, side population; MP, main population; iTRAQ, isobaric tags for relative and absolute quantification; 2D LC-MS/MS, two-dimensional liquid chromatography-tandem mass spectrometry.

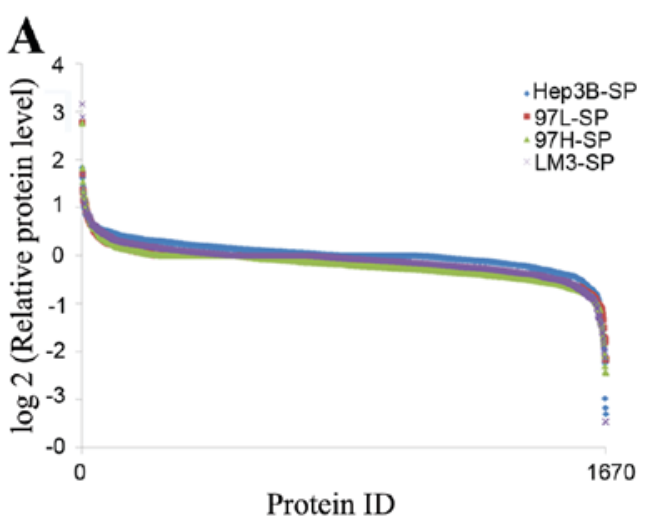

B

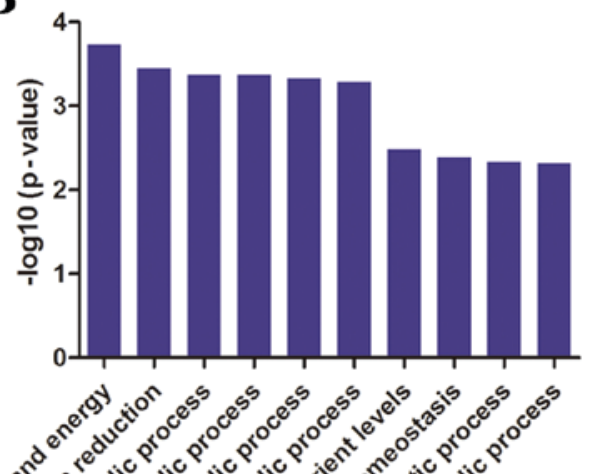

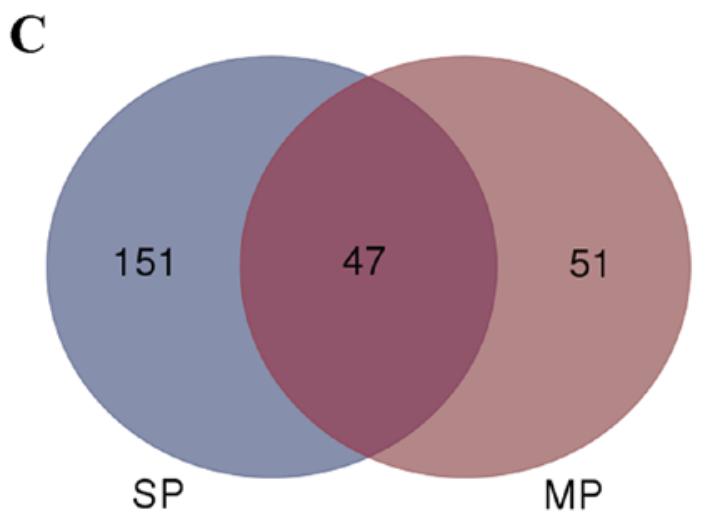

Figure 3. Features of the SP cell proteome dataset revealed by isobaric tags for relative and absolute quantification analysis. (A) Analysis of the relative protein level revealed a protein abundance dynamic range of 7 orders of magnitude. (B) Results of Gene Ontology analysis. (C) Venn diagrams demonstrate the total number of DEPs in the SP and MP groups when LM3-SP cells were compared with Hep3B-SP cells and LM3-MP cells were compared with Hep3B-MP cells. SP, side population; DEP, differentially expressed protein; MP, main population; LM3, HCCLM3. 

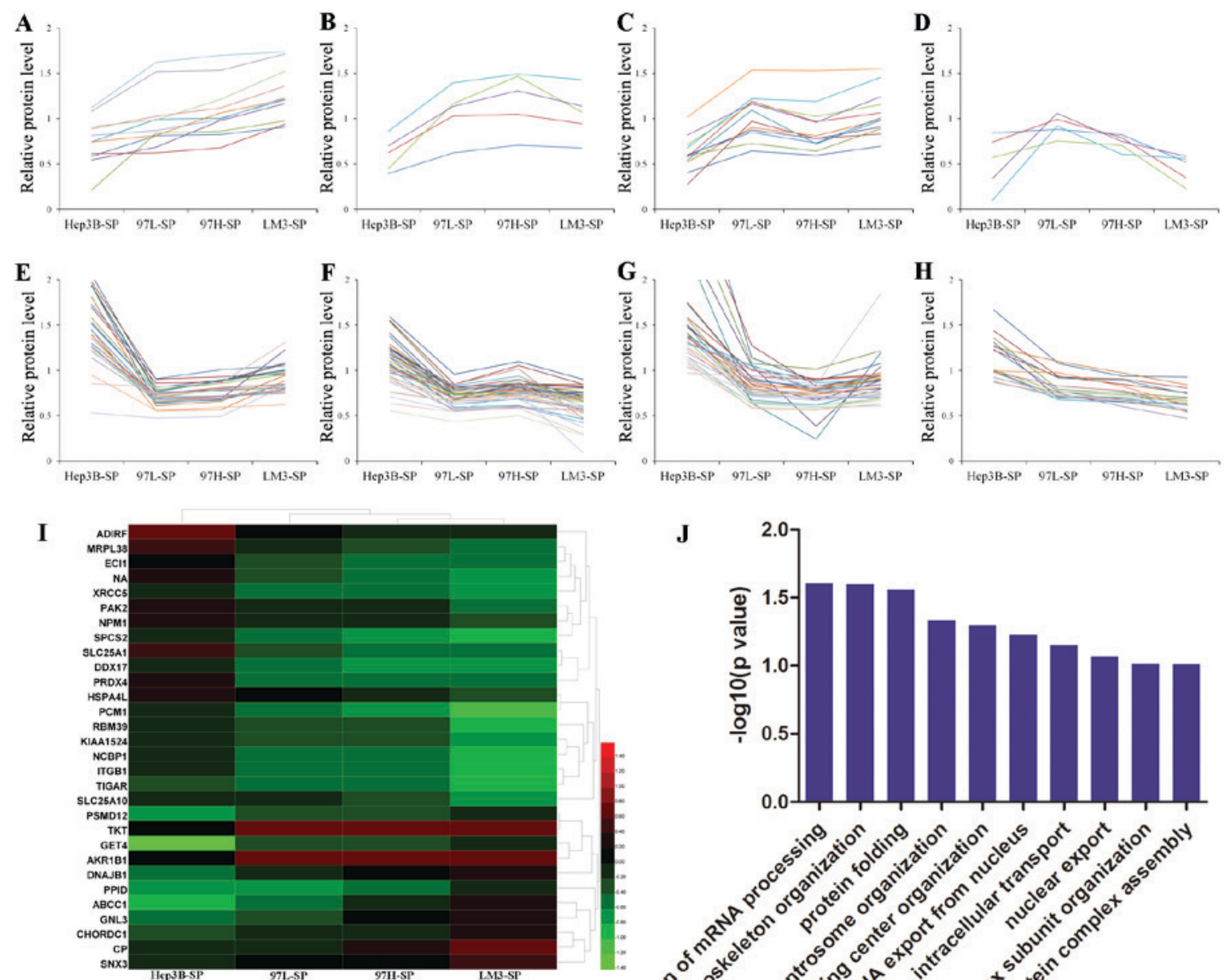

$\mathbf{J}$
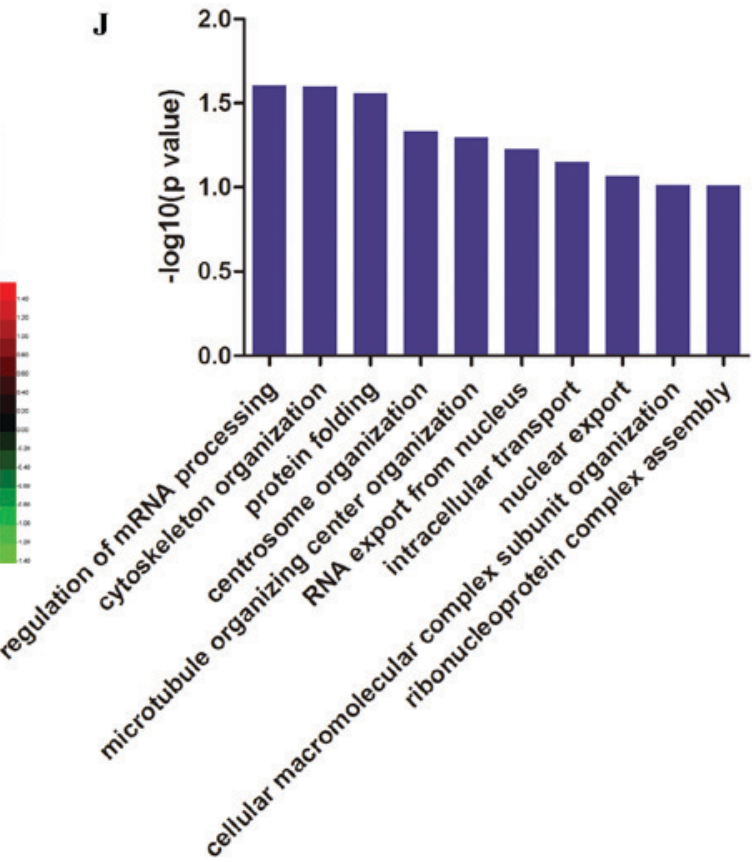

Figure 4. Expression trends, hierarchical clustering and biological processes analysis of the DEPs. Expression trends of 151 DEPs in SP cells. (A) The relative protein level of DEPs increased progressively from Hep3B-SP to 97L-SP, to 97H-SP, to LM3-SP cells. (B-G) Types are the proteins which are altered non-linearly. (B) The relative protein level of DEPs follows the trend of Hep3B-SP<97L-SP<97H-SP $>$ LM3-SP. (C) The relative protein level of DEPs follows the trend of Hep3B-SP< 97L-SP $>97 \mathrm{H}-\mathrm{SP}<\mathrm{LM} 3-\mathrm{SP}$. (D) The relative protein level of DEPs follows the trend of Hep3B-SP $<$ 97L-SP $>97 \mathrm{H}-\mathrm{SP}>\mathrm{LM} 3-\mathrm{SP}$. (E) The relative protein level of DEPs a follows the trend of Hep3B-SP $>97 \mathrm{~L}-\mathrm{SP}<97 \mathrm{H}-\mathrm{SP}<\mathrm{LM} 3-\mathrm{SP}$. (F) The relative protein level of DEPs follows the trend of Hep3B-SP $>97 \mathrm{~L}-\mathrm{SP}<97 \mathrm{H}-\mathrm{SP}>\mathrm{LM} 3-\mathrm{SP}$. (G) The relative protein level of DEPs follows the trend of Hep3B-SP $>97 \mathrm{~L}-\mathrm{SP}>97 \mathrm{H}-\mathrm{SP}<\mathrm{LM} 3-\mathrm{SP}$. (H) The relative protein level of DEPs decreased progressively from Hep3B-SP to LM3-SP cells. (I) Hierarchical clustering analysis of the 30 DEPs that were upregulated or downregulated with increasing metastatic potentials. The relative protein level of DEPs are presented: Red indicates a relative protein level $>1$ and green indicates a relative protein level <1. (J) Gene Ontology analysis of the 30 DEPs in terms of biological processes. DEPs, differentially expressed proteins; SP, side population; 97L, MHCC97-L; 97H, MHCC97-H; LM3, HCCLM3.

distinct clusters, as illustrated in the heatmap in Fig. 4I, and were mainly involved in 'regulation of mRNA processing' and 'cytoskeleton organization' biological processes according to GO analysis (Fig. 4J). Furthermore, the majority of these proteins were involved in the process of 'self-renewal', 'chemoresistance' and 'metastasis' in various types of cancer, and they may promote $\mathrm{HCC}$ migration in a synergistic manner. Transketolase (TKT) has been demonstrated to promote cell proliferation and metastasis in various types of cancer and is associated with poor survival of patients with HCC (26-28). Targeting TKT has been demonstrated to lead to increased oxidative stress, causing increased sensitivity of cancer cells to therapeutic treatments, including Sorafenib (29). ATP binding cassette subfamily $\mathrm{C}$ member 1 (30), integrin subunit $\beta 1$ (ITGB1) $(31,32)$ and aldo-keto reductase family 1 member B $(33,34)$ have been reported to be involved in chemoresistance/radioresistance and cancer metastasis. P21-activated kinase 2 (35), G protein nucleolar 3 (36), nucleophosmin (37) and pericentriolar material 1 (38) have been associated with metastatic characteristics in various types of cancer. These results indicate that different SP cells may have different molecular mechanisms for metastatic initiation, regulation, and evasion of conventional HCC chemotherapies.

Pathways and networks identified by IPA analysis. To further elucidate the possible molecular mechanisms of tumorigenesis 


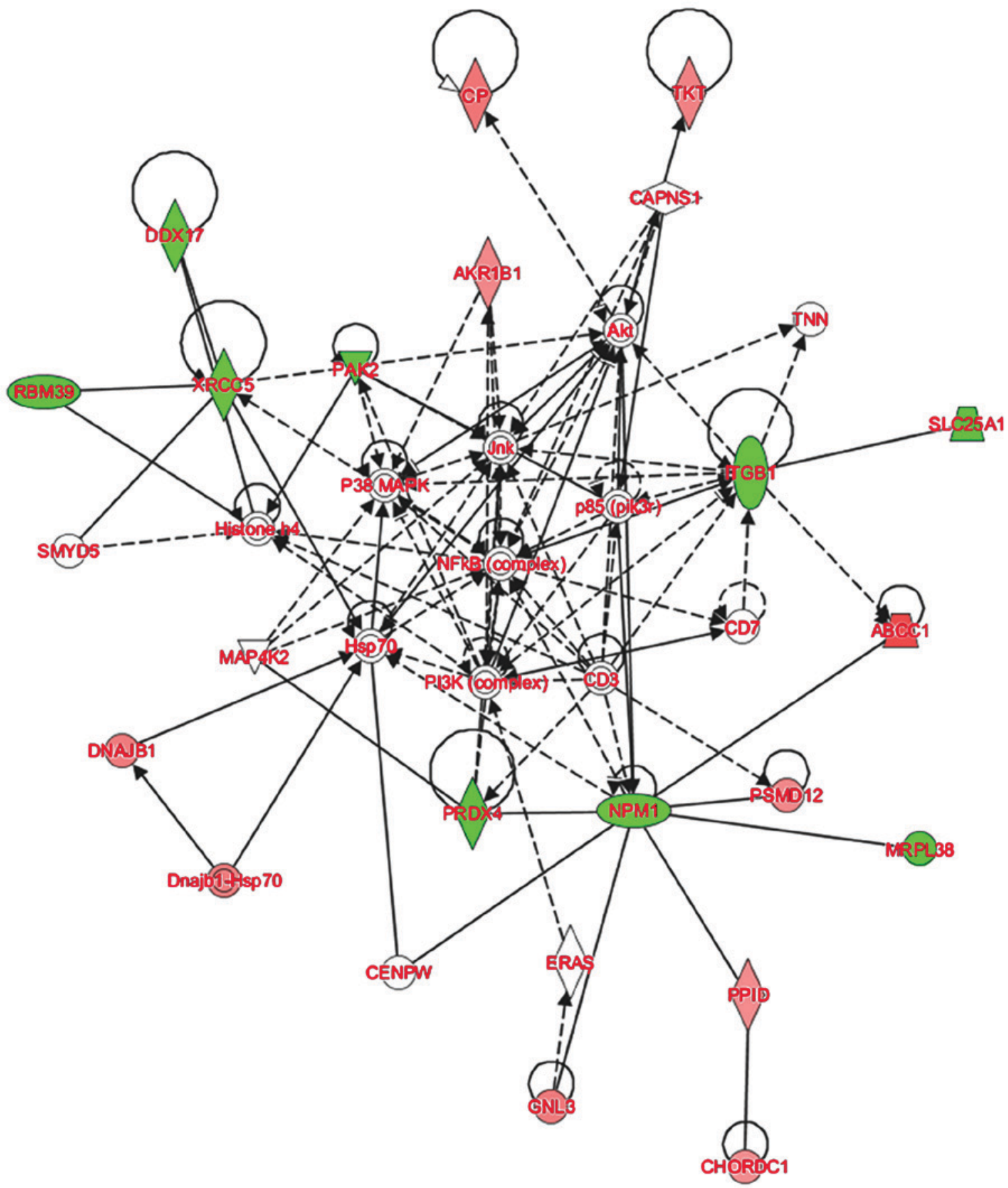

Figure 5. The AKT and NF-кB signaling pathways were demonstrated to be involved in the function of SP-cell derived from all 4 cell lines. Red indicates the upregulated proteins and green indicates the downregulated proteins. Solid lines indicate direct interactions and dotted lines indicate indirect interactions.

and metastasis of SP cell groups, IPA software was used to analyze the signaling pathways in which the DEPs were involved. The IPA analysis demonstrated that the majority of the 30 DEPs altered linearly between SP cell groups were involved in the regulation of AKT and nuclear factor- $\kappa \mathrm{B}(\mathrm{NF}-\kappa \mathrm{B})$ signaling (Fig. 5). AKT signaling is associated with the regulation of cell proliferation, differentiation, apoptosis and glucose transport (39). The AKT signaling pathway is also associated with cell invasion and migration (40). Cluster of differentiation (CD)133 has been demonstrated to promote gallbladder carcinoma cell migration by activating AKT phosphorylation (41). The AKT signaling pathway has been associated with CSC-like properties and epithelial-mesenchymal transition (EMT) features of A549/CDDP cells (42). In the network assembled in the present study, ITGB1 was indicated to affect AKT indirectly, and TKT and CP are downstream of AKT signaling. Furthermore, NF- $\mathrm{kB}$ signaling is central to the network. It has been reported that the NF- $\mathrm{kB}$ signaling contributes to the invasive and metastatic capabilities of CSCs through modulation of the extracellular environment or through cell-intrinsic changes, including EMT $(43,44)$. Therefore, the results of the present study suggest that in $\mathrm{HCC}, \mathrm{AKT}$ and NF- $\mathrm{\kappa B}$ signaling may contribute to the regulation of HCC metastasis through regulating the DEPs expressed in CSC-like SP cells. These results suggest that the quantitative proteomics approach used was suitable for studying the overall molecular profile changes 
of different SP cells in HCC, and provide insight into the potential molecular mechanisms of this effect.

\section{Discussion}

Although surgical resection has been the first-line treatment for HCC in recent decades, the prognosis of HCC patients remains poor (45). Post-surgical metastasis and recurrence are the main causes of the high mortality rate and poor prognosis of HCC (46). To achieve a longer survival time, the identification of novel therapeutic targets associated with HCC invasion and metastasis is required. CSCs are thought to cause cancer development, and to be the primary cause of tumor relapse and metastasis (47). Thus, CSC-targeted therapeutic approaches may have great potential in HCC.

CSCs have been identified in several types of malignant tumor, including breast (48), brain (49), prostate (50), lung (51), gastric (52), colon (53) and pancreatic (54) cancers, as well as melanoma (55). Recently, research has revealed the existence of CSCs in HCC (56). With the exception of SP identification, several surface markers are used including CD133 (57), CD90 (58), CD44 (59), epithelial cell adhesion molecule (60), oval cell marker 6 (61), and aldehyde dehydrogenase (62) are employed. Although cells expressing different combinations of these markers possess CSC properties, heterogeneity in metastatic potential is observed. It was reported that $\mathrm{CD} 90+\mathrm{CD} 44+$ cells demonstrated a more aggressive phenotype compared with CD90+CD44- cells, and formed metastatic lesions in the lungs of immunodeficient mice (58). CD133+CD44+ HCC cells isolated from HCC cell lines have been demonstrated to exhibit an improved ability to initiate tumor formation and lung metastasis compared with CD133+CD44- cells (63).

In the present study, SP cells were isolated from 4 HCC cell lines and their abilities to self-renew and migrate were compared. The results demonstrate that SP cells from different HCC lines possess similar self-renewing abilities and differing metastatic potentials, which is consistent with the results of previous studies $(64,65)$. Furthermore, through a comprehensive analysis of DEPs, significant differences among the 4 SP cell groups were demonstrated at the proteome level. The expression levels of 11 and 19 proteins were upregulated and downregulated, respectively, with increased metastatic potential. The majority of these proteins were demonstrated to be involved in 'cell proliferation', 'migration' and 'invasion of cancer', and they may promote HCC metastasis in a synergistic manner. This hypothesis was supported by the results of IPA analysis, which indicated alteration of the AKT and $\mathrm{NF}-\kappa \mathrm{B}$ signaling pathways, which have been demonstrated to be associated with the regulation of migration and invasion in a number of types of cancer (66-68).

Numerous markers have been identified which are indicative of CSCs in the context of HCC. However, such cells exhibit significant heterogeneity between laboratories (69). The proportion of cells expressing specific markers also varies between HCC cell lines. For example, CD133+ cells cannot be detected in numerous HCC cell lines and clinical HCC samples (11). SP cells are also heterogeneous; however, they are mainly identified by the expression of ABC transporters, including $\mathrm{ABCB} 1$ and $\mathrm{ABCG} 2$ (70). SP identification provides an alternative method of identification when definite markers of CSCs are uncharacterized. There are limitations to all CSC isolation strategies, therefore, a combination of different isolation methods may be required.

To the best of our knowledge, this is the first report to investigate the overall proteome variations among SP cells from HCC cell lines with different metastatic potentials. The present study provides novel information regarding of the metastatic potential of CSCs, which will facilitate further investigation. Further research, such as a genomic-transcriptomic combination study, is required to fully elucidate the underlying molecular mechanisms of CSC metastatic potential.

\section{Acknowledgments}

Not applicable.

\section{Funding}

The present study was supported by the specialized Science and Technology Key Project of Fujian Province (grant no. 2013YZ0002-3), the Science and Technology Infrastructure Construction Program of Fujian Province (grant no. 2014Y2005), the National Natural Science Foundation of China (grant nos. 31201008 and 31400634), the Natural Science Foundation of Fujian Province (grant no. 2015J05174), the Scientific research project of Health and Family Planning Commission of Fujian Province (grant no. 2015-1-94), the Scientific Foundation of Fuzhou Health Department (grant no. 2014-S-139-3, 2015-S-wq12) and the Scientific Foundation of Fuzhou City (grant no. 2013-S-125-4).

\section{Availability of data and materials}

The datasets generated and/or analyzed during the current study are available at [http://www.iprox.org/index] with the iProx ID: IPX00078600.

\section{Authors' contributions}

HL, YW, XL and JL participated in the conception and design of the study. HL, XX and YS performed the proteomic studies and LC-MS/MS analysis. HL and YW performed cell culture and cell functional assays. QL and SC performed FCM analysis. HL, XX, GC and DW performed data analysis. HL, YW, $\mathrm{XX}$ and DW participated in data interpretation. All authors read and approved the final manuscript.

\section{Ethics approval and consent to participate}

Not applicable.

\section{Consent for publication}

Not applicable.

\section{Competing interests}

The authors declare that they have no competing interests. 


\section{References}

1. Ferlay J, Soerjomataram I, Dikshit R, Eser S, Mathers C, Rebelo M, Parkin DM, Forman D and Bray F: Cancer incidence and mortality worldwide: Sources, methods and major patterns in GLOBOCAN 2012. Int J Cancer 136: E359-E386, 2015.

2. Chen W, Zheng R, Baade PD, Zhang S, Zeng H, Bray F, Jemal A, $\mathrm{Yu}$ XQ and He J: Cancer statistics in China, 2015. CA Cancer J Clin 66: 115-132, 2016.

3. Shah SA, Cleary SP, Wei AC, Yang I, Taylor BR, Hemming AW, Langer B, Grant DR, Greig PD and Gallinger: Recurrence after liver resection for hepatocellular carcinoma: Risk factors, treatment, and outcomes. Surgery 141: 330-339, 2007.

4. Bruix J and Sherman M; American Association for the Study of Liver Diseases: Management of hepatocellular carcinoma: An update. Hepatology 53: 1020-1022, 2011.

5. Tang Z: Hepatocellular carcinoma-cause, treatment and metastasis. World J Gastroenterol 7: 445-454, 2001.

6. Guo Z, Li LQ, Jiang JH, Ou C, Zeng LX and Xiang BD: Cancer stem cell markers correlate with early recurrence and survival in hepatocellular carcinoma. World J Gastroenterol 20: 2098-2106, 2014.

7. Yu Z, Pestell TG, Lisanti MP and Pestell RG: Cancer stem cells. Int J Biochem Cell Biol 44: 2144-2151, 2012.

8. Giannelli G, Bergamini C, Fransvea E, Marinosci F, Quaranta V and Antonaci S: Human hepatocellular carcinoma (HCC) cells require both alpha3beta1 integrin and matrix metalloproteinases activity for migration and invasion. Lab Invest 81: 613-617, 2001

9. Chen W, Chen L, Cai Z, Liang D, Zhao B, Zeng Y, Liu X and Liu J: Overexpression of annexin A4 indicates poor prognosis and promotes tumor metastasis of hepatocellular carcinoma. Tumor Biol 37: 9343-9355, 2016.

10. Hermann PC, Huber SL, Herrler T, Aicher A, Ellwart JW, Guba M, Bruns CJ and Heeschen C: Distinct populations of cancer stem cells determine tumor growth and metastatic activity in human pancreatic cancer. Cell Stem Cell 1: 313-323, 2007.

11. Shi GM, Xu Y, Fan J, Zhou J, Yang XR, Qiu SJ, Liao Y, Wu WZ, $\mathrm{Ji} \mathrm{Y}, \mathrm{Ke} \mathrm{AW}$, et al: Identification of side population cells in human hepatocellular carcinoma cell lines with stepwise metastatic potentials. J Cancer Res Clin Oncol 134: 1155-1163, 2008.

12. Goodell MA, Brose K, Paradis G, Conner AS and Mulligan RC: Isolation and functional properties of murine hematopoietic stem cells that are replicating in vivo. J Exp Med 183 1797-1806, 1996.

13. Chiba T, Kita K, Zheng YW, Yokosuka O, Saisho H, Iwama A, Nakauchi $\mathrm{H}$ and Taniguchi $\mathrm{H}$ : Side population purified from hepatocellular carcinoma cells harbors cancer stem cell-like properties. Hepatology 44: 240-251, 2006.

14. Wang J, Guo LP, Chen LZ, Zeng YX and Lu SH: Identification of cancer stem cell-like side population cells in human nasopharyngeal carcinoma cell line. Cancer Res 67: 3716-3724, 2007.

15. Ho MM, Ng AV, Lam S and Hung JY: Side population in human lung cancer cell lines and tumors is enriched with stem-like cancer cells. Cancer Res 67: 4827-4833, 2007.

16. Haraguchi N, Utsunomiya $\mathrm{T}$, Inoue $\mathrm{H}$, Tanaka $\mathrm{F}$, Mimori $\mathrm{K}$, Barnard GF and Mori M: Characterization of a side population of cancer cells from human gastrointestinal system. Stem Cells 24: 506-513, 2006

17. Ross PL, Huang YN, Marchese JN, Williamson B, Parker K, Hattan S, Khainovski N, Pillai S, Dey S, Daniels S, et al: Multiplexed protein quantitation in Saccharomyces cerevisiae using amine-reactive isobaric tagging reagents. Mol Cell Proteomics 3: 1154-1169, 2004.

18. Aggarwal K, Choe LH and Lee KH: Shotgun proteomics using the iTRAQ isobaric tags. Brief Funct Genomic Proteomic 5: 112-120, 2006

19. Xing X, Huang Y, Wang S, Chi M, Zeng Y, Chen L, Li L, Zeng J, Lin M, Han X, et al: Comparative analysis of primary hepatocellular carcinoma with single and multiple lesions by iTRAQ-based quantitative proteomics. J Roteomics 128: 262-271, 2015.

20. Wei D, Zeng Y, Xing X, Liu H, Lin M, Liu X and Liu J: Proteome differences between hepatitis B virus genotype-Band genotype-C-induced hepatocellular carcinoma revealed by iTRAQ-based quantitative proteomics. J Proteome Res 15: 487-498, 2015

21. Huang X, Zeng Y, Xing X, Zeng J, Gao Y, Cai Z, Xu B, Liu X, Huang A and Liu J: Quantitative proteomics analysis of early recurrence/metastasis of huge hepatocellular carcinoma following radical resection. Proteome Sci 12: 22, 2014.
22. Ko CH, Cheng CF, Lai CP, Tzu TH, Chiu CW, Lin MW, Wu SY, Sun CY, Tseng HW, Wang CC, et al: Differential proteomic analysis of cancer stem cell properties in hepatocellular carcinomas by isobaric tag labeling and mass spectrometry. J Proteome Res 12: 3573-3585, 2013.

23. Xu Y, Xie Y, Wang X, Chen X, Liu Q, Ying M and Zheng Q: Identification of cancer stem cells from hepatocellular carcinoma cell lines and their related microRNAs. Oncol Rep 30: 2056-2062, 2013

24. Yu Y, Shen H, Yu H, Zhong F, Zhang Y, Zhang C, Zhao J, Li H, Chen J, Liu Y and Yang P: Systematic proteomic analysis of human hepotacellular carcinoma cells reveals molecular pathways and networks involved in metastasis. Mol Biosyst 7: 1908-1916, 2011

25. Chen N, Sun W, Deng X, Hao Y, Chen X, Xing B, Jia W, Ma J, Wei H, Zhu Y, et al: Quantitative proteome analysis of HCC cell lines with different metastatic potentials by SILAC. Proteomics 8: 5108-5118, 2008.

26. Ricciardelli C, Lokman NA, Cheruvu S, Tan IA, Ween MP, Pyragius CE, Ruszkiewicz A, Hoffmann P and Oehler MK: Transketolase is upregulated in metastatic peritoneal implants and promotes ovarian cancer cell proliferation. Clin Exp Metastasis 32: 441-455, 2015.

27. Li J, Zhu SC, Li SG, Zhao Y, Xu JR and Song CY: TKTL1 promotes cell proliferation and metastasis in esophageal squamous cell carcinoma. Biomed Pharmacother 74: 71-76, 2015.

28. Tan GS, Lim KH, Tan HT, Khoo ML, Tan SH, Toh HC and Ching Ming Chung M: Novel proteomic biomarker panel for prediction of aggressive metastatic hepatocellular carcinoma relapse in surgically resectable patients. J Proteome Res 13: 4833-4846, 2014.

29. Xu IM, Lai RK, Lin SH, Tse AP, Chiu DK, Koh HY, Law CT, Wong CM, Cai Z, Wong CC and Ng IO: Transketolase counteracts oxidative stress to drive cancer development. Proc Natl Acad Sci USA 113: E725-E734, 2016.

30. Chow AK, Ng L, Lam CS, Wong SK, Wan TM, Cheng NS, Yau TC, Poon RT and Pang RW: The Enhanced metastatic potential of hepatocellular carcinoma (HCC) cells with sorafenib resistance. PLoS One 8: e78675, 2013.

31. Lu Y, Hu J, Sun W, Li S, Deng S and Li M: MiR-29c inhibits cell growth, invasion, and migration of pancreatic cancer by targeting ITGB1. Onco Targets Ther 9: 99, 2015.

32. Broustas CG and Lieberman HB: RAD9 enhances radioresistance of human prostate cancer cells through regulation of ITGB1 protein levels. Prostate 74: 1359-1370, 2014.

33. Nakarai C, Osawa K, Akiyama M, Matsubara N, Ikeuchi H, Yamano T, Hirota S, Tomita N, Usami M and Kido Y: Expression of AKR1C3 and CNN3 as markers for detection of lymph node metastases in colorectal cancer. Clin Exp Med 15: 333-341, 2015.

34. Dan S, Shirakawa M, Mukai Y, Yoshida Y, Yamazaki K, Kawaguchi T, Matsuura M, Nakamura Y and Yamori T: Identification of candidate predictive markers of anticancer drug sensitivity using a panel of human cancer cell lines. Cancer Sci 94: 1074-1082, 2003.

35. Sato M, Matsuda Y, Wakai T, Kubota M, Osawa M, Fujimaki S, Sanpei A, Takamura M, Yamagiwa S and Aoyagi Y: p21-activated kinase-2 is a critical mediator of transforming growth factor- $\beta$-induced hepatoma cell migration. J Gastroenterol Hepatol 28: 1047-1055, 2013.

36. Lee M, Williams KA, Hu Y, Andreas J, Patel SJ, Zhang S and Crawford NP: GNL3 and SKA3 are novel prostate cancer metastasis susceptibility genes. Clin Exp Metastasis 32: 769-782, 2015.

37. Ching RH, Lau EY, Ling PM, Lee JMF, Ma MK, Cheng BY, Lo RC, Ng IO and Lee TK: Phosphorylation of Nucleophosmin at Threonine 234/237 is associated with HCC metastasis. Oncotarget 6: 43483-43495, 2015

38. Ueo H, Takano Y, Matsumura T, Kurashige J, Shinden Y, Eguchi H, Sudo T, Sugimachi K, Saeki H, Oki E, et al: Identification of genes that predict lymph node metastasis in colorectal cancer cases. Fukuoka Igaku Zasshi 104: 559-563, 2013 (In Japanese)

39. Song G, Ouyang G and Bao S: The activation of Akt/PKB signaling pathway and cell survival. J Cell Mol Med 9: 59-71, 2005.

40. Martini M, De Santis MC, Braccini L, Gulluni F and Hirsch E: PI3K/AKT signaling pathway and cancer: An updated review. Ann Med 46: 372-383, 2014.

41. Li C, Wang C, Xing Y, Zhen J and Ai Z: CD133 promotes gallbladder carcinoma cell migration through activating Akt phosphorylation. Oncotarget 7: 17751-17759, 2016. 
42. Wang H, Zhang G, Zhang H, Zhang F, Zhou B, Ning F, Wang HS Cai SH and Du J: Acquisition of epithelial-mesenchymal transition phenotype and cancer stem cell-like properties in cisplatin-resistant lung cancer cells through AKT/ $\beta$-catenin/Snail signaling pathway. Eur J Pharmacol 723: 156-166, 2014

43. Mani SA, Guo W, Liao MJ, Eaton EN, Ayyanan A, Zhou AY, Brooks M, Reinhard F, Zhang CC, Shipitsin M, et al: The epithelial-mesenchymal transition generates cells with properties of stem cells. Cell 133: 704-715, 2008 .

44. Rinkenbaugh AL and Baldwin AS: The NF- $\mathrm{B}$ pathway and cancer stem cells. Cells 5: pii: E16, 2016.

45. Wang FS, Fan JG, Zhang Z, Gao B and Wang HY: The global burden of liver disease: The major impact of China. Hepatology 60: 2099-2108, 2014.

46. Margonis GA, Sasaki K, Andreatos N, Nishioka Y, Sugawara T, Amini N, Buettner S, Hashimoto M, Shindoh J and Pawlik TM: Prognostic impact of complications after resection of early stage hepatocellular carcinoma. J Surg Oncol 115: 791-804, 2017.

47. Chiba T, Iwama A and Yokosuka O: Cancer stem cells in hepatocellular carcinoma: Therapeutic implications based on stem cell biology. Hepatol Res 46: 50-57, 2016.

48. Al-Hajj M, Wicha MS, Benito-Hernandez A, Morrison SJ and Clarke MF: Prospective identification of tumorigenic breast cancer cells. Proc Natl Acad Sci USA 100: 3983-3988, 2003

49. Singh SK, Clarke ID, Terasaki M, Bonn VE, Hawkins C, Squire J and Dirks PB: Identification of a cancer stem cell in human brain tumors. Cancer Res 63: 5821-5828, 2003.

50. Collins AT, Berry PA, Hyde C, Stower MJ and Maitland NJ: Prospective identification of tumorigenic prostate cancer stem cells. Cancer Res 65: 10946-10951, 2005.

51. Kim CF, Jackson EL, Woolfenden AE, Lawrence S, Babar I, Vogel S, Crowley D, Bronson RT and Jacks T: Identification of bronchioalveolar stem cells in normal lung and lung cancer. Cell 121: 823-835, 2005.

52. Takaishi S, Okumura T, Tu S, Wang SS, Shibata W, Vigneshwaran R, Gordon SA, Shimada Y and Wang TC: Identification of gastric cancer stem cells using the cell surface marker CD44. Stem Cells 27: 1006-1020, 2009.

53. Ricci-Vitiani L, Lombardi DG, Pilozzi E, Biffoni M, Todaro M, Peschle C and De Maria R: Identification and expansion of human colon-cancer-initiating cells. Nature 445: 111-115, 2007.

54. Li C, Heidt DG, Dalerba P, Burant CF, Zhang L, Adsay V, Wicha M, Clarke MF and Simeone DM: Identification of pancreatic cancer stem cells. Cancer Res 67: 1030-1037, 2007.

55. Schatton T, Murphy GF, Frank NY, Yamaura K, Waaga-Gasser AM, Gasser M, Zhan Q, Jordan S, Duncan LM, Weishaupt $\mathrm{C}$, et al: Identification of cells initiating human melanomas. Nature 451: 345-349, 2008

56. Yang ZF, Ngai P, Ho DW, Yu WC, Ng MN, Lau CK, Li ML, Tam KH, Lam CT, Poon RT and Fan ST: Identification of local and circulating cancer stem cells in human liver cancer. Hepatology 47: 919-928, 2008.

57. Ma S, Chan KW, Hu L, Lee TK, Wo JY, Ng IO, Zheng BJ and Guan XY: Identification and characterization of tumorigenic liver cancer stem/progenitor cells. Gastroenterology 132: 2542-2556, 2007.
58. Yang ZF, Ho DW, Ng MN, Lau CK, Yu WC, Ngai P, Chu PW, Lam CT, Poon RT and Fan ST: Significance of CD90+ cancer stem cells in human liver cancer. Cancer Cell 13: 153-166, 2008.

59. Zhu Z, Hao X, Yan M, Yao M, Ge C, Gu J and Li J: Cancer stem/progenitor cells are highly enriched in CD133+CD44+ population in hepatocellular carcinoma. Int J Cancer 126 2067-2078, 2010.

60. Yamashita T, Ji J, Budhu A, Forgues M, Yang W, Wang HY, Jia H, Ye Q, Qin LX, Wauthier E, et al: EpCAM-positive hepatocellular carcinoma cells are tumor-initiating cells with stem/progenitor cell features. Gastroenterology 136: 1012-1024, 2009.

61. Yang W, Wang C, Lin Y, Liu Q, Yu LX, Tang L, Yan HX, Fu J, Chen Y, Zhang HL, et al: OV6+ tumor-initiating cells contribute to tumor progression and invasion in human hepatocellular carcinoma. J Hepatol 57: 613-620, 2012.

62. Ma S, Chan KW, Lee TK-W, Tang KH, Wo JY, Zheng BJ and Guan XY: Aldehyde dehydrogenase discriminates the CD133 liver cancer stem cell populations. Mol Cancer Res 6: 1146-1153, 2008.

63. Ma S: Biology and clinical implications of CD133(+) liver cancer stem cells. Exp Cell Res 319: 126-132, 2013.

64. Yang X, Wang J, Qu S, Zhang H, Ruan B, Gao Y, Ma B, Wang X, Wu N, Li X, et al: MicroRNA-200a suppresses metastatic potential of side population cells in human hepatocellular carcinoma by decreasing ZEB2. Oncotarget 6: 7918-7929, 2015.

65. Zhou L, Yang ZX, Song WJ, Li QJ, Yang F, Wang DS, Zhang N and Dou KF: MicroRNA-21 regulates the migration and invasion of a stem-like population in hepatocellular carcinoma. Int J Oncol 43: 661-669, 2013.

66. Li J, Deng Z, Wang Z, Wang D, Zhang L, Su Q, Lai Y, Li B, Luo Z, Chen X, et al: Zipper-interacting protein kinase promotes epithelial-mesenchymal transition, invasion and metastasis through AKT and NF-kB signaling and is associated with metastasis and poor prognosis in gastric cancer patients. Oncotarget 6 : 8323-8338, 2015

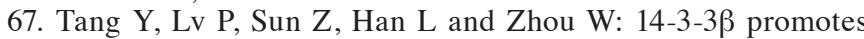
migration and invasion of human hepatocellular carcinoma cells by modulating expression of MMP2 and MMP9 through PI3K/Akt/NF- $\mathrm{B}$ pathway. PLoS One 11: e0146070, 2016.

68. Wang YH, Dong YY, Wang WM, Xie XY, Wang ZM, Chen RX, Chen J, Gao DM, Cui JF and Ren ZG: Vascular endothelial cells facilitated HCC invasion and metastasis through the Akt and $\mathrm{NF}-\kappa \mathrm{B}$ pathways induced by paracrine cytokines. J Exp Clin Cancer Res 32: 51, 2013.

69. Chen Y, Yu D, Zhang H, He H, Zhang C, Zhao W and Shao R: CD133(+)EpCAM(+) phenotype possesses more characteristics of tumor initiating cells in hepatocellular carcinoma Huh7 cells. Int J Biol Sci 8: 992-1004, 2012.

70. Moitra K: Overcoming multidrug resistance in cancer stem cells. Bio Med Res Int 2015: 635745, 2015.

This work is licensed under a Creative Commons Attribution-NonCommercial-NoDerivatives 4.0 International (CC BY-NC-ND 4.0) License. 